\title{
Strengthening Rural Decentralisation: A Study on the Role of International Organisations
}

\author{
Dr Sujit Kumar Paul ${ }^{+}$
}

\section{Abstract}

The term 'decentralisation' has generally been used to refer to a variety of institutional reforms. It has sometimes been considered as a change in the organisational framework in which political, social and economic decisions are made and implemented. It is also understood as a mechanism to transfer responsibility and authority. In recent years, decentralisation has received singular attention all over the world. It has been considered as one of the most important elements in development strategy. It is a global and regional phenomenon, and most countries have attempted to implement it as a tool for development, as a political philosophy, and as a mechanism for sharing responsibility at different levels.

Since 1980s, developing countries have increasingly adopted decentralised form of governance. Decentralisation means the transfer of authority and responsibility from central to intermediate and local governments. Although the democratic decentralisation in terms of Panchayati Raj Institutions (village councils) was a post-Independence phenomenon, there has been a legacy and tradition of village panchayats since time immemorial in India. The 73rd and 74th Amendment Act, 1993 of the Constitution of India has made the Panchayat an institution of self-government. As per the constitution, Panchayats shall prepare plan for economic development and social justice at their level. The District Planning Committee shall integrate the plan so prepared with the plans prepared by the local bodies at district level. The success and failure of the Panchayats would depend on planning and implementation. It also depends on maximum people's participation at every stage of planning process, from proposal to implementation. People's participation in locallevel development has been exercised through the formulation of the Panchayat-level development plan, project coordination at intermediate and district levels of the Panchayats.

The Panchayati Raj Institutions (PRIs) in West Bengal are very strong bodies, which function as real institutions of self-governance. In West Bengal, the planning process of grass-root level has some stages from proposal to implementation. After introduction of 3-tier Panchayat system in 1978, the Government of West Bengal brought about need-based reforms in the system from time to time from the very beginning. Encouraged by the State Government's strong commitment to rural decentralisation, Department for International Development (DFID), Government of UK came forward to support the ongoing rural decentralisation initiatives and upscale the bottom-up planning process. In the present study, an attempt has been made to understand the role of DFID for strengthening decentralisation in rural Bengal.

Key words: decentralisation, planning, implementation, development, rural West Bengal, India

\footnotetext{
${ }^{\dagger}$ Associate Professor, Department of Lifelong Learning and Extension, Institute of Rural Reconstruction, Visva-Bharati (A Central University), Sriniketan - 731236, Birbhum, West Bengal, India \& Vice President, Association for World Education (AWE) - An International NGO with consultative status of the United Nations. Emails: skpaulrd@gmail.com, sujit_kakali@rediffmail.com

(C2014 Paul. This is an Open Access article distributed under the terms of the Creative Commons Attribution License (http://creativecommons.org/licenses/by/2.0), which permits unrestricted use, distribution, and reproduction in any medium, provided the original work is properly cited.
} 


\section{Introduction}

Decentralisation means the transfer of authority, legislative, judicial or administrative, from central to intermediate and local governments. The term 'decentralisation' has generally been used to refer to a variety of institutional reforms. It is considered as a change in the organisational framework in which political, social and economic decisions are made and implemented. Mahatma Ganjdhiji's idea on Gram Swaraj seems appropriate and timely in current period. Indeed, his political philosophies on Gram Swaraj have now come into existence in the form of Gram Panchayat, which is an effective instrument of grassroots governance and participative development. Evidences from Indian history suggest that the village panchayats were responsible for local problem solutions within the village level. In the Vedic era, there was "Panch-Ayat", which means a group of five people who were selected by the villagers and they were responsible for local governance. 'Sabha', 'Samiti', and 'Vidath' these terms are mentioned in the Rigveda as local self-units. The Ramayana and the Mahabharata both indicate local selfgovernance in the Epic era. Terms such as Gram, Maha gram are mentioned in the Ramayana. Kautilya's Arthashastra too states that 'Sabha' and 'Samiti' played a vital role in controlling the decisions of the king. Besides, Neeti Shastra of Shukracharya also mentions village governance during ancient period. During the Sultanate period, the sultans divided their kingdom into provinces like 'Vilayat' and 'Amir'. Village was the smallest unit and had sufficient powers for local self-governance. Panchayats were also prevalent in the villages in the medieval period. According to Maheswari (1985), the beginning of local government can be presumed from 1687, when the Madras City Corporation was established. The British period divided into four timelines, that is, from 1687-1881, local governments were established to share the burden of resources of the central and provincial governments; 1882-1919, local governments were viewed as local self-government; 1920-
1937, local governments were established and people's representatives were controlling the provincial administration, and from 1938-1947, local governments were in the state of rejuvenation and reconstruction (Joshi and Narwani, 2002). After India's independence in 1947 , the village panchayats were included in the Indian Constitution. According to Article 40 of the Indian Constitution, "the state should take steps to organise Village Panchayats and endow them with such power and authority as may be necessary to enable them to function as units of self-government." Rajasthan was the first state where Panchayati Raj was established on 2nd October 1959. This followed the establishments of the Panchayati Raj Institution as a unit of local self-governance in every states of India.

The 73rd Amendment Act has made Panchayats an institution of self-government. Article 243G of the Constitution envisaged Panchayats as Institute of Self Governance (ISG), which means they should enjoy functional, financial and administrative autonomy in their working area. As per the Constitution, Panchayats shall prepare plan for economic development and social justice at local level. The District Planning Committee shall integrate the plan so prepared with the plans prepared by the urban local bodies at district level.

The success and failure of the Panchayats would depend on planning and implementation. It also depends on maximum people's participation at every stage of planning process, from proposal to implementation. People's participation in locallevel development has been exercised through the formulation of the panchayat-level development plan, project coordination at intermediate and district levels of the panchayats.

In West Bengal, the Gram Panchayats have been given more powers in comparison with powers given to the Block/District Panchayats. They have 14 obligatory and 21 assigned functions, apart from a large number of discretionary functions. The gram panchayats have full power to approve works. The 
Panchayat Samities also perform a large variety of functions related to 18 sectors. The Zilla Parishads have a wide range of administrative and financial powers. They are delegated with all the functions of 29 sectors under schedule XI with 17 other items and 24 departmental schemes for implementation.

The State Government has brought about needbased reforms in the panchayat system from time to time from the very beginning. A major reform was creation of Gram Sansad (village parliament with electors regarded as parliamentarians) at village level. Next, the State Government also created Gram Unnayan Samiti (village development committee) elected by the electors of each Gram Sansad (GS) to enhance people's participation and to assist Gram Panchayats to plan, implement and monitor activities for economic development and social justice. Notwithstanding, its planning process was not decentralised until the seventh plan period. In the next section, an attempt has been made to discuss the methodology of decentralised planning.

\section{Methodology of Decentralised Planning in West Bengal}

In West Bengal, the planning process of grassroot level has some stages from proposal to implementation. At first, the Gram Unnayan Samiti prepares the local area plans and those plans are then submitted in the Gram Sansad meeting. Following this, all local area plans of all Gram Sansads are taken to the Gram Sabha. The Gram Sabhas are convened to identify the problems of development and the local needs. Special efforts are made to ensure participation of the people. The most important guideline in this matter is to arrange group-wise discussion in each Gram Sabha according to various development sectors. After the identification of the felt needs in the Gram Sabhas, the next step in the planning process is to make an objective assessment of the natural and human resources of the locality. The reports of the Gram Sabha discussion, including list of problems identified are consolidated for each development sector in the panchayat.
After receiving the final plan from Panchayats, the Panchayat Samiti (Block Council) and Zilla Parishad (District Council) starts preparing their annual plans. The plan proposal are consolidated at the district level and integrated with the Municipal plans. The task force constituted by the District Planning Committee (DPC) for the purpose evolves broad strategy for district-level development, the district plan is nothing but only the synthesis of the village plans. Currently, the rules favour the implementation of planned activities by the Zilla Parisad. The DPC forwards the integrated development plan for rural and urban areas of the district to the State. The State Planning Board is the state-level coordinating agency for planning. Next, I discuss the decentralised planning scenario in West Bengal.

\section{Scenario of Decentralised Planning}

The state government of West Bengal decided to go for a decentralised planning from the seventh five-year plan period (1985-1989). In the 1980s, the block-level planning and the district-level planning were formulated and implemented. However, the process of implementation and formulation of the district planning committee was reformed after the 73rd and 74th Amendment Act of the Constitution of India, 1993. In order to attract people's participation in large numbers, the Gram Sabha (Village Council meeting) and Gram Sansad (Village Constituency) were also created in the districts. As per the State Cabinet (1999), the Department of Planning and Development released an order (Memo no. 1415/P/2M-6/99-dated 24.05.1999) for allocation of the united fund for implementation of the district plans at the district level. The village-level plans are prepared by the Gram Unnayan Committee (Village Development Committee), which are then finalised in the Gram Sansad Meeting. In addition, in these Gram Sabha meetings the final consolidated plans of the Panchayat level are prepared from all the Sansad-level plans. Action plans prepared by the Gram Panchayats are integrated into Block Plans and again the same is linked into the District Plans and 
incorporating therein, the District Sector Scheme and District Plans are formulated. The planning structure of West Bengal, thus bear four levels of consolidation.

The West Bengal government divides the budget for the plans into two segments: State Sector Scheme and District Sector Scheme. The District Planning Committee after discussion with the State Government decides some area for development and planning such as: 1. Area Specific Agricultural Product, 2. Extension of technical services, storage and marketing facilities, 3. Minor irrigation, 4. Mahatma Gandhi National Rural Employment Guarantee Act (MGNREGA), 5. Social Forestry, and 6. Animal husbandry, etc.

The PRIs have a significant role to empower as well as develop the rural people. As stated earlier, people's participation play an important role for successful decentralization of planning process. However, in West Bengal the participation of both female and male are very low and remains a key lacuna to decentralisation. Most meetings are compelled to be dissolved due to the lack of coram. In reality, due to very poor level of awareness among the villagers and heavy workload between both men and women of the rural areas, their participation remains extremely low. The Gram Sabha (meeting held twice in a year under Gram Panchayat) has another important role in the decentralised planning process. Gram Panchayat makes final plans in the presence of all adult voters of that panchayat but here too the participation is very poor when compared to the total voters of these two panchayats.

For the decentralised planning to be successful, the local people of the particular Panchayat need to realise their roles and responsibilities. However, it is evident that at the time of Gram Sabha and Gram Sansad meetings people remain engaged in their daily chores. Another observable but important thing is the misinformation that are circulated about the dates and times of the meetings. Apparently, most villagers remain unaware about their roles in planning and implementation processes.
Again, some socially active villagers remain prejudiced to participate in the development process because the plans prepared by them are seldom implemented. Seemingly, politicisation of the entire planning process is further hampering the process of decentralisation because at the time of planning and implementation, priority is mostly given on the basis of political involvement of those areas where the influential persons who can speak and bear oratory skills take the upper hand in the meetings and the common people's opinion tend to be ignored. Middle- and upperclass villagers are simply not interested to attend the meetings because they think that the government programmes are mainly in favour of the marginal or poor community. Evidently, most villagers believe that the PRIs are nothing but ruling party's institutions.

Funds for decentralised planning at district level, block level and panchayat level comes from (i) own income of the local bodies, (ii) funds from the State Government and (iii) various government-sponsored programme on cost sharing between the Central and State Government. To implement the micro-level plan, it is necessary that there is an uninterrupted flow of funds to the gram panchayat. However, the Planning Commission of India is yet to strengthen this system. Moreover, for the process of financial devolution, the panchayats depend on the State Government for funding, the allocation of which is highly insufficient, that is, limited fund to implement any plans and availability of fund mostly at the fag end of the financial year. Wherever the panchayats receive sufficient funds, they fail to utilise the entire fund due to the lack of proper infrastructure, poor quality of plans and limited capacity. The other impediments that stand in the way of plan implementation are administrative and bureaucratic interference, lack of technological know-how, improper budget estimation and non-submission of utilisation certificate in time by the office of the panchayat. Despite these drawbacks, the West Bengal Government remains committed to rural decentralisation. The next section discusses the role of the 
Department of International Development (DFID), Government of UK who came forward to support the ongoing rural decentralisation initiatives and upscale the bottom-up planning process.

\section{Intervention of DIFD for Strengthening Decentralization in Rural Bengal}

\section{Background \& Inception of the Strengthening Rural Decentralisation (SRD) Programme}

Here, an attempt has been made to understand the role of DFID in strengthening decentralisation in rural Bengal. As stated above, encouraged by the West Bengal Government's strong commitment to rural decentralisation, DFID came forward to support the ongoing rural decentralisation initiatives and upscale the bottom-up planning process. The Government accepted the offer since the process of decentralisation for good governance, focus on poverty alleviation was already a priority, and the assistance from DFID would expedite the process. However, through a number of studies during design and postdesign phase of the programme for Strengthening Rural Decentralisation (SRD) with support from DFID, the State Government identified further areas in PRI functioning, which needed systemic improvements in quality of governance with wider and better participation, greater transparency, accountability and responsiveness towards the poor for economic development with more equity and social justice.

In agreement with DFID, the Programme for Strengthening Rural Decentralisation (SRD) was designed by Panchayats \& Rural Development Department, Government of West Bengal (nodal Department for rural decentralisation) in 2003. The representatives of DFID, Govt. of India and the State Government appraised the Programme Design in 2004. The Project Concept Note approved by the appropriate authorities in the UK and India in 2002 had recommended for a support of $£ 150$ million; but at the time of appraisal of the Programme Design, DFID reduced the size of the grant to $£ 130$ million over seven years. Finally, DFID sanctioned $£ 9$ million only for the first two years' activities, indicating that the remainder of the grant would be available for five more years subject to fulfilment of the targets and attainment of the milestones in the first two years. After clearance from the Government of India in October 2005, the programme was inaugurated on 22nd November 2005 in Kolkata by Honourable Chief Minister of West Bengal. Implementation of the programme was started by Panchayats \& Rural Development Department.

\section{The Changing Scenario}

As already established, the purpose of the SRD programme is to support the State Government to strengthen and accelerate the ongoing process of rural decentralisation leading to sustainable reduction in poverty in the rural areas of the state. Major thrust was given on institutional strengthening of Gram Panchayats and institutionalisation of participatory planning, implementation and monitoring processes in 304 selected Gram Panchayats in the six districts: Purulia, Malda, Murshidabad, Uttar Dinajpur, Dakshin Dinajpur and Birbhum. One of the agendas in the initial phase was to create examples of success for other Gram Panchayats to follow and also to reiterate that the programme interventions are worth replication and wide upscaling in the next phase. Following are among the notable changes due to the support of DFID.

\section{Sustainable Institutional (Panchayats) Development}

As noted earlier, for the sustainable development of the programme, emphasis was given in strengthening the PRIs. The SRD process resulted in preparation and publication of a draft roadmap for the Panchayats in West Bengal - a Vision Document by Panchayats \& Rural Development Department. Since selfassessment and self-monitoring remain the crux for strengthening the institutions, these two have been introduced in the system of PRIs. Panchayats in West Bengal now track their own progress over time, which help them to develop a baseline on the basis of their own appraisal. 


\section{Capacity Building}

It has been possible to strengthen about 300 Gram Panchayats and 3500 Gram Unnayan Samities in six districts as institutions through specially designed capacity-building interventions (individual, organisational and institutional) as a result of which these institutions are performing more effectively in terms of the constitutional mandate for economic development and social justice. In other words, due to capacity-building interventions and handholding support through the programme, these functionaries of around 300 are now conversant with better financial management including accounting and audit compliance. Computerised accounting system introduced at Gram Panchayat level is being up scaled with the programme support in these six districts.

Training and awareness generation is an important part for capacity building. It has been possible to generate awareness among all the Gram Panchayats across the state about the scope and necessity of enhancement of their own source revenue (both tax and non-tax), as a result of which the quantum of resources to be generated by the Gram Panchayats will increase manifold. With SRD programme support, 294 Gram Panchayats in the six districts have a minimum training infrastructure to cope with the increasing training needs at the community level.

\section{Development of Infrastructure}

With SRD programme support, the Extension Training Centres have been established with better training infrastructure to perform more effectively. Entire state has been provided with computers and peripherals among other things for improving their work environment. To facilitate direct training of a large number of Panchayat functionaries, a satellite-based Training and Development Communication Channel Network has been installed. The system has proved to be a very powerful tool of information dissemination, monitoring and capacity building on distance education mode. The SRD programme has taken special initiative for mass awareness and mobilising community through various strategic campaign interventions including extensive use of the folk media and an interactive radio programme.

\section{Community-Based Plans}

Due to intense facilitation with the SRD programme support and intense participation of communities including the poorest and the marginalised sections, it has been possible to install Gram Sansad Plan based on Gram Panchayat planning process in 304 Gram Panchayats and about 4000 Gram Sansads. These plans are community-based, communityowned and community-managed. These Gram Panchayats have been able to demonstrate positive evidence of convergence of initiatives of Gram Panchayats and of the line departments for improved delivery of essential services like development of Anganwadi Centres, improvement of enrolment in Primary Schools, effective functioning of self-help groups, etc.

Around 3500 Gram Unnayan Samitis under these Gram Panchayats are now implementing community-based and community-owned plans, as a part of the Gram Panchayat plans, with focus on low-tech and low-cost activities, ensuring and dovetailing community contributions (around 20\% of their total budgets) and Untied Poverty Fund available under the SRD Programme. In order to invoke participation of the community and ensure transparency, accountability and inclusiveness, the Gram Unnayan Samitis shared the summary of their annual plan budgets with each and every household in the respective areas. Most of the Untied Poverty Funds under the SRD programme are utilised by Gram Unnayan Samitis through disadvantaged self-help groups and indigent households, identified at Gram Sansad level, for social development and livelihoods expansion.

The SRD programme has been able to create thousands of evidences of community initiative, participatory democracy, transparency and meeting so-far-unperceived needs of the communities in the areas of public health, education and expansion of livelihoods. The examples of success are significantly 
stimulating replication in the neighbouring areas with community initiatives.

\section{Implementation of Various Schemes}

The Central and the State Governments in India continue to implement various welfare, development and employment-generation schemes such as Swarnajayanti Gram Swarojgar Yojana (SGSY), MGNREGA, through the panchayats. The SRD is managing and supervising the implementation of the work by observing all necessary formalities. The common people and the Gram Panchayat functionaries expressed satisfaction at the quality and quantity of the work done. The Gram Panchayat recognised the SRD-facilitated planning process as an important factor behind the achievement.

\section{Conclusion}

Successful planning and implementation of development programmes require adequate funds, appropriate policy framework and effective delivery mechanism with healthy environment for decentralisation. After the 73rd and 74th Amendment, the Government is trying to change in planning process by adopting bottom-up approach. The success has raised immense expectation about replication of the processes statewide on 'SRD mode'. It has been observed that if the process is replicated in the entire state, there will be tangible transformation in institutional practices, enhanced resource mobilisation, improved financial management, participatory planning, social mobilisation and voice, transparency, inclusiveness and accountability - all leading to reduction of poverty. The interventions on SRD mode need to be started in all tiers of PRIs and across all the districts of the state for better outcome out of investments made for rural development.

\section{References}

Bandyopadhyay, D. (2004): Panchayats and Democracy - Elites versus Dalits, in New Issues in Panchayati Raj, Ed. by D. Bandyopadhyay and Amitava Mukherjee, Task Force on Panchayati Raj, Rajiv Gandhi Foundation, Concept Publication, New Delhi-59
Chakrabarty Sukhamoy (1994): Problems of Plan Implementation; Ed. by Terence J. Byres, The State and Development Planning in India, Oxford University Press Publication, New Delhi01

Jana Anil Kumar (2004): Administering District Planning in India, Concept Publishing Company Published, New Delhi-59

Jain, S.P. (1980): Decentralization in India: An Appraisal, in Public Governance and Decentralization, Ed. by Mishra S.N., Dutta Mishra Anil and Mishra Sweta, Mittal Publication, New Delhi.

Joshi, R.P.; Narwani, G.S. (2002): Panchayat Raj in India - Emerging Trends across the States, Rawat Publications, Jaipur and New Delhi.

Maheshwari, Shriram (1985): Rural Development in India - A Public Policy Approach, SAGE Publications, New Delhi.

Majumder, Sankar (2002): Methodological Issues in Village-Based Decentralized District Planning; Indian Institute of Advanced study Publication, Shimla.

Pal, Mahi (2004): From "Raj" Governance to "Swaraj" Governance-Progress, Performance and Perspective, Kurukshetra - A Journal on Rural Development, Vol-52, No-10, August 2004.

Pal, Mahi (2004): Panchayati Raj and Development, Yojana - A Development Monthly, Vol-48, August 2004.

Report on the Programme for SRD, SRD Cell, Department of Panchayat and Rural Development, Government of West Bengal.

Roy, Dipen (2005): Finance and Accounting of Panchayat Raj Institution in West Bengal, Abhijit Publication, New Delhi-94.

Singh, S.P. (2004): Capacity Building of Gram Sabha for Efficient Local Governance, Kurukshetra - A Journal on Rural Development, Vol-52, No-10, and August 2004.

Singha Sisodia, Yatindra (2006): People's Participation on Gram Sabha - A Case Study of Rural Madhya Pradesh, Kurukshetra - A Journal on Rural Development, Vol-54, No-7, May 2006. 
Verma, R.M. (2004): Panchayat Raj - Rhetoric \& Reality, Kurukshetra - A Journal on Rural Development, Vol-52, No-10, August 2004.

11th Five Year Plan and Annual Plan for Birbhum, 2007-2011. published by Birbhum District Planning Committee, Birbhum, West Bengal. 